\title{
Tonsillectomy efficacy is comparable to the standard medical treatment in PFAPA syndrome
}

\author{
G Vigo ${ }^{*}$, G Martini, S Zoppi, F Vittadello, F Zulian \\ From 18th Pediatric Rheumatology European Society (PReS) Congress \\ Bruges, Belgium. 14-18 September 2011
}

\section{Background}

PFAPA syndrome is the most common cause of periodic fever in childhood. Tonsillectomy has been recently suggested as an effective treatment but little is known about its long-term efficacy.

\section{Aim}

To evaluate the clinical features, response to treatment and disease outcome in a large cohort of patients with PFAPA syndrome.

\section{Methods}

We conducted a retrospective study on patients with clinical diagnosis of PFAPA syndrome followed at a tertiary center from January 1993 to August 2010. Clinical and laboratory parameters have been evaluated at onset and during the follow-up. Disease remission was considered as the absence of symptoms for at least one year. Disease outcome in patients who underwent tonsillectomy was compared to those treated with standard medical therapy (NSAIDs, prednisone).

\section{Results}

275 patients with PFAPA syndrome were identified, 59.6\% males, mean age at onset 27.9 months (range 1132 ), mean duration of symptoms 40.5 months (10-122). A positive family history for PFAPA in first degree relatives was found in 86 patients $(31.2 \%)$. The percentage of patients responding to tonsillectomy, 27/41 (65.8\%), was not significantly different of what observed in those on standard therapy, $137 / 232$ patients $(59 \%)$ treated with just medical treatment $(\mathrm{p}=0.51)$. Neither the mean disease duration, in months, (39.7 vs 39.9 ) nor the age

\footnotetext{
* Correspondence: giulia.gmv@libero.it

Rheumatology Unit, Department of Pediatrics, University of Padua, Padua, Italy
}

at remission (5.6 vs 5.5 ) were significantly different in both groups.

\section{Conclusions}

In a large cohort of patients with PFAPA syndrome, tonsillectomy did not offer a significant advantage in comparison with the standard medical treatment.

Published: 14 September 2011

doi:10.1186/1546-0096-9-S1-P26

Cite this article as: Vigo et al:: Tonsillectomy efficacy is comparable to the standard medical treatment in PFAPA syndrome. Pediatric Rheumatology 2011 9(Suppl 1):P26.
Submit your next manuscript to BioMed Central and take full advantage of:

- Convenient online submission

- Thorough peer review

- No space constraints or color figure charges

- Immediate publication on acceptance

- Inclusion in PubMed, CAS, Scopus and Google Scholar

- Research which is freely available for redistribution

\section{() Biomed Central}

\section{Biomed Central}

